\title{
CORPORATE SOCIAL RESPONSIBILITY OF THE SELECTED TRANSPORT COMPANY OPERATED ON THE CZECH MARKET
}

\author{
Simona Činčalová, Zuzana Nováková \\ College of Polytechnics Jihlava, Czech Republic \\ E-mail: simona.cincalova@vspj.cz, zuzana-novak@seznam.cz
}

\begin{abstract}
Corporate social responsibility is a much-discussed topic because it includes an inexhaustible number of activities in the economic, social and environmental fields. The basic theoretical basis of social responsibility is applied to a specific Czech company. A questionnaire for the employees of the subsidiary helped with the research. It was found that the company is doing very well in corporate social responsibility (CSR) activities and has a good portfolio for compiling a comprehensive CSR report, which is a proposal as one of the measures. Another area suitable for the development of some activities is the ecological part. The company actively supports the ecological approach and behaviour, and it has set some measures, such as ISO 14001 certification at its gas station branches, so it is well on its way to certifying its office buildings.
\end{abstract}

Keywords: corporate social responsibility, transport industry, Czech Republic

\section{Introduction}

The concept of corporate social responsibility (CSR) has never been clearly defined (Sankar, 2021). This may be due in particular to the voluntary basis and the absence of strict rules for the application of CSR activities. Organizations can still choose which path to social responsibility (Chen et al., 2020).

In principle, however, the company is always seen as a body that is not isolated from the environment but interacts with society. This relationship brings rights and obligations to this society, and it should lead not only to economic growth but also to an increase in quality of life (Ullah \& Sun, 2021). This can help a company to succeed commercially. Peloza \&Shang (2011), for example, point out the ambiguity of the CSR concept: "socially responsible behaviour can mean different things in different places for different people at different times." According to Abeysekera \& Fernando (2020), inconsistencies in CSR understanding are limiting further research and measurements.

Dahlstud analysed several dozen definitions of CSR in his work How to Corporate Social Responsibility is defined: an analysis of 37 definitions (Dahlsrud, 2008) and thus identified the five most common terms:

- environmental area,

- social area,

- economic area,

- stakeholders,

- voluntariness. 
Simona ČINČALOVÁ, Zuzana NOVÁKOVÁ. Corporate social responsibility of the selected transport company operated on the Czech market

OF MANAGEMENT IN THE $21^{\text {st }}$ CENTURY Vol. 16, No. 2, 2021

By applying the mechanism, a cycle is created, at the end of which all incoming stakeholders (all interested parties) and the given company should be satisfied at the same time. Specific activities are integrated into the company's business strategies so that short-term goals are replaced by long-term goals, and maximum profit is thus optimal. Therefore, CSR must be linked to the subject of business, so that it is not just a short-term marketing tool. Gradual education of the company in this area has made CSR a very good competitive tool.

Vurro and Perrini (2011) claim that making the most of CSR activities has a positive impact on performance. Lee et al. (2012), Bučiuniené et al. (2012), Vilanova et al. (2009) show that a well-established CSR has a positive effect on business revenues. Turban and Greening (1996) examined CSR activities for large US businesses and found that corporate social responsibility had a positive impact on the return on assets. According to these positive impacts, the authors aimed to analyse CSR activities of the selected company and set up the recommendations for improving.

\section{Research Methodology}

For sharing of research results, the selected company wishes to remain anonymous, therefore it will be referred to as the Transport Company. Several researchers deal with the transport companies in their studies and emphasize the importance of research into this sector (e.g., Arimany Serrat et al., 2019; Martin, 2020; Velinov \& Činčalová, 2021). The Transport Company is headquartered in Prague and in 2021 employed approximately 1,000 people from 30 countries. It has been operating in the market of integrated road mobility solutions and has been operating in the B2B (business to business) market for 25 years. Customers are companies doing business in logistics. The company offers a fuel card system for paying fuel, tolls and some other travel expenses. It has expanded its fuel payment network to almost 15,000 service stations across Europe and the Middle East. It operates several own gas stations in Europe. Transport Company owns 17 subsidiaries, thanks to which it can provide its customers with some other services related to road transport.

Regarding the research methods, the information was drawn from informal interviews with five of company's employees from the relevant departments, from the company's annual reports, from the company's website and the company's internal communication with the employees. The next step in the research was a questionnaire survey in the segment of employees in the subsidiary Transport Company in the Czech Republic, where 41 people were employed at the time, the questionnaire was sent out. This segment was selected as a representative sample of the company, as the CSR activities of the Transport Company are equally applied in all its subsidiaries.

\section{Research Results}

\section{Economic Area}

Transport Company has a public code of ethics, which is set as the basic basis for the conduct of the entire internal group, including subsidiaries. It commits itself to ethical behaviour towards stakeholders, compliance with social responsibility and Czech and international legislation. He expects the same from his business partners and suppliers.

The company relies heavily on the selection of suppliers and business partners. In addition to practical criteria such as reliability, market feedback, speed of delivery and price, he is interested in ISO certification and analyses the ethics of their business, including compliance with legislation, before starting cooperation. The company also works with the threat of potential support for terrorism in connection with Act No. 253/2008 Coll., On certain measures 
against money laundering and terrorist financing, and avoids cooperation with suppliers who

process conflict minerals.

Transport Company applies an anti-corruption policy and has developed an anticorruption document accessible to all employees. The document defines corrupt practices and contains a matrix of donations and acceptances of donations. The appropriate department checks compliance with these principles and reports on the results of inspections. The company states here, for example, that all its charitable donations are not the subject of a marketing strategy.

The quality control of services is carried out by external audits and in the Czech company by maintaining the ISO 9001 certification for the quality management system. QMS (quality management system) is further evaluated by regular internal audits. The focus of internal audits is mainly in response to complaints or other customer complaints or relevant employee suggestions for process improvement. One of the controlled processes is CDP (clean desk policy), where the company regularly audits a selected sample of employees and their compliance with this principle.

The selected company operates in international markets and has customers from all over Europe and the Middle East. It realizes that face-to-face and native language communication is the number one solution for caring for relationships and trustworthiness. It, therefore, has a liaison office and a sales representative in each country. During the Covid-19 pandemic, she created smaller projects that can help customers in their day-to-day activities - arranging protective equipment, up-to-date information on measures, etc. The company regularly reviews the NPS (net promoter score); others) among customers, where a short questionnaire is used to determine the level of loyalty and overall satisfaction with the company.

Building trust is important for Transport Company not only in the customer segment but also in other groups, such as business partners, suppliers and other companies, including employees. It, therefore, strives to be transparent and shares its results and actions in annual and press releases.

\section{Social Area}

Transport Company follows the motto that one dissatisfied employee will influence five other people around him (meaning family, friends, colleagues, etc.). It, therefore, deals with the satisfaction of its employees and their loyalty to the company and annually generates an ENPS (employee net promoter score) questionnaire. Based on the results, it creates additional measures. An example would be enabling sick days.

For easier orientation in the code of ethics, it compiled its cross-section into the form of 4 values, which it considers to be the basic building block for functioning in both internal and external society. The values focus on responsibility at work, development and innovation, and the second part reflects responsible behaviour towards people and philanthropic thinking. The explanations of values are intertwined and are set so that they are easy to remember and capture the company's mindset.

The company is aware that its development depends on the talent of employees and therefore strives to apply the strategy of talent management, talent search and training following the needs of the organization, e.g., with external partners creating workshops for leadership development.

The development and training of employees rank the company in the first position in their care. The company provides individual language courses with lecturers of its choice, organizes workshops to improve work in internal systems and seeks education in other areas such as child psychology, climate change, etc. During the onset of the Covid-19 pandemic and subsequent more frequent work from the home office, the HR department created training blocks in which it advises employees on how to deal with this regime. 
Simona ČINČALOVÁ, Zuzana NOVÁKOVÁ. Corporate social responsibility of the selected transport company operated on the Czech market

PROBLEMS

OF MANAGEMENT

IN THE $21^{\text {st }}$ CENTURY

Vol. 16, No. 2, 2021

During the sudden situation of social distance, the company felt an even greater need to work to strengthen team spirit. The HR department created several activities to strengthen communication and improve the atmosphere - photo competitions on various topics, workshops on working with communication systems and taking care of the physical and mental wellbeing of the body. During normal years, without anti-pandemic restrictions, the department organizes team building and other social events, which aim to improve communication and subsequent coordination between individual teams. The protection of employees' health, which Transport Company strives for by enabling regular medical examinations and training in the field of occupational safety, can also be included in this category. At the beginning of the Covid-19 pandemic, it changed its short-term strategy and placed the need to protect the health of its employees in the first place, which it wanted to achieve by introducing some additional measures beyond those of the government. In addition to physical health, he continues to try to take care of the mental and provides employees with psychological counselling at an external partner.

In addition to the possibility of education and personal growth, employees have the opportunity to draw some other benefits. The annual financial benefit is an annual bonus, which is calculated from the previous evaluation of the direct superior. This evaluation is based on the employee's self-reflection. Here he gets the opportunity to comment on his position and set goals for the next period. Each employee will also receive a certain amount in the cafeteria benefit plus, which they can also handle according to their own needs (meal vouchers, supplementary pension insurance, life insurance, medical procedures, purchase of products and services in the acceptance network, etc.). Other benefits include the use of services provided by the company, such as the possibility of preferential refuelling in the acceptance network of company cards, etc. One of the last benefits is the possibility of taking 5 days of leave beyond the legislative provisions.

The company strives to maintain the work-life balance of its employees and thus create a calm atmosphere and eliminate stress. In addition to the possibility of taking above-standard holidays, they have the opportunity to work at home offices, sliding working hours and sick days. With the possibility of working from home, the Covid-19 pandemic increased rapidly. The home office has become a condition and the evaluation of the questionnaire survey will specify in more detail how the perception of the distance work process by employees has changed.

\section{Environmental Area}

The Transport Company strives to create new solutions for integrated mobility with a neutral impact on the environment. It has therefore set up a department for electromobility and alternative fuels, where it creates new services to support customers with vehicles with alternative propulsion and invests in its commitments to promote more environmentally friendly transport. The next step is the publication of a document that aims to open a stakeholder debate on "clean mobility" in Europe and sets out how $\mathrm{CO}_{2}$ emissions can be reduced and what measures are needed to make the transition to electromobility effective. In addition to the unresolved issues regarding the infrastructure for electromobility, the company draws attention to the potential threat of reducing oil production, and the possible economic collapse of the Middle East and Africa and wants to further develop this issue. Public discussions with the company's management show that the Green Agreement is seen as something that must come into force for environmental sustainability, and as a commitment of the whole of European society.

Czech filling stations and truck washing stations are ISO 14001 certified (standards for the environmental management system), and certification of filling stations in other countries are currently being prepared. To obtain this certification, the company is obliged to monitor 
Simona ČINČALOVÁ, Zuzana NOVÁKOVÁ. Corporate social responsibility of the selected transport company operated on the Czech market

energy consumption, water and waste production, and comply with all related regulations. Furthermore, it has set an environmental policy, which aims to eliminate the impact on the

PROBLEMS

OF MANAGEMENT

IN THE $21^{\text {st }}$ CENTURY

Vol. 16, No. 2, 2021 environment. Its compliance is monitored by regular internal audits. Consumption in buildings is dealt with by the energy audit according to 406/2000 Coll.

The Transport Company supports waste sorting. In addition to standard plastic and paper storage facilities, it has set up containers for electrical waste and batteries at its Prague headquarters.

\section{Questionnaire Survey}

The questionnaire survey was conducted in the subsidiary Transport Company based in South Bohemia. CSR activities are the same as in the parent company, the subsidiary takes over the code of ethics, benefits and reflects other CSR activities of the company. The subsidiary has 41 employees, and 35 employees responded to the questionnaire in this structure:

- gender: 31 women and 4 men,

- age: lower than 25 years - 5 people, 26-35 years - 14 , 36-45 years -14 , more than 46 years -2 ,

- years working for the company - less than 1 year -6 people, 2-5 years $-20,6-10$ years -8 , more than 11 years -1 .

The questionnaire survey showed that the company's employees are largely familiar with the concept of CSR and feel that the company behaves responsibly towards the company, especially in caring for them. Before entering the work process, only a minimum of employees, mostly younger, were interested in the CSR of the Transport Company. From this, it can be concluded that the interest in CSR of the employer is growing, and the younger generation is especially interested.

\section{Figure 1}

The Most Important Benefits for Employees. Source: Own Collaboration

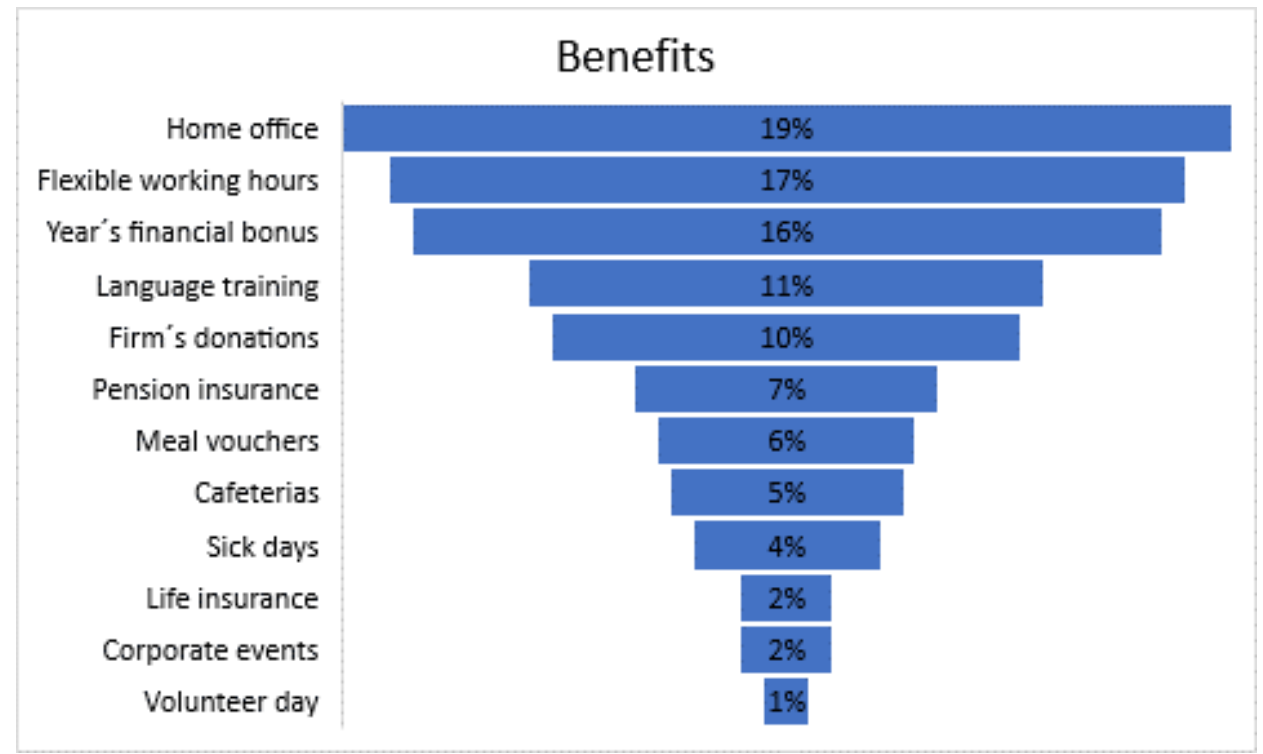

The Transport Company offers a wide range of employee benefits. Employees consider the possibility of working from a home office and flexible working hours to be the most 
Simona ČINČALOVÁ, Zuzana NOVÁKOVÁ. Corporate social responsibility of the selected transport company operated on the Czech market

OF MAN

NAGEMENT

IN THE $21^{\text {st }}$ CENTURY Vol. 16, No. 2, 2021

important (see Figure 1). This result may be due to the pandemic situation of Covid-19 in the Czech Republic. The judgment is based on the question of the perception of the home office after a year of pandemics, where most employees still feel safe thanks to it and consider it a good solution to this situation where the work-life balance must occur more than usual. The overall internal solution to the pandemic situation can be assessed as positive. The company was able to respond and adapt the rules to the situation, either through the rapid introduction of a home office or internal communication.

\section{Discussion}

According to the theoretical background and the results of the research, the authors suggest several recommendations for improving the CSR activities and their implementation in the Transport Company.

The company actively encourages its employees to use volunteer day. They offer several possible projects or organizations to take advantage of and help such a day, however, these are projects around the headquarters. Following this, it is recommended to analyse potential volunteer activities directly at the locations of other branches and present them to employees as an opportunity, then help them with organizational requirements, as well as Licandro (2017) or Saz-Gil et al. (2020) mention. This is likely to lead to greater employee participation in smaller branches.

To introduce a new activity in the social external field, it would be appropriate to organize blood donation under the auspices of the company. Given the number of employees of the Transport Company, it would be appropriate for it to take advantage of this and contact the employees for this activity (Gershon \& Cryder, 2018). As part of this, you can apply a motivational bonus in the form of a small reward or collect different symbols for each subscription.

Given the size of the Transport Company, it is clear that its carbon footprint will not be negligible. One of the recommendations is to prepare an analysis of the total production of greenhouse gases, not only at gas stations with ISO 14001 certificate in a more detailed analysis, e.g., paper volume). Determining the carbon footprint will primarily improve the environment but will allow the Transport Company to have a better overview and subsequent cost optimization in its office buildings. The company can then become carbon-neutral by compensating for the carbon dioxide produced, which can be considered a positive trend and a way to improve competitiveness (Modak \& Kelle, 2021; Redwood, 2013).

Another recommendation in the field of ecology is the creation of social activities at the level of employees and their families (Chalupa et al., 2021). An example can be the organization of mass cleaning of nature and the motivation of people for this activity, such as photo competitions, etc.

Containers for basic waste sorting are located in all the company's buildings. Only employees of the Prague branch have the opportunity to properly sort electrical waste and batteries within the company. The recommendation in this regard is to place containers for electrical waste and batteries in other buildings and thus educate all employees about the importance of sorting other waste (Öztay \& Birinci, 2019).

As part of the analysis of CSR activities, it was not found that Transport Company comprehensively presented these activities to its stakeholders. The company has great potential to better grasp such a presentation, as the individual areas can be considered very developed here. At the same time, ISO 26000 certification based on three areas of CSR or the use of other guidelines for non-financial reporting, such as GRI, can be recommended. These standards are used internationally and, given the company's position, would further contribute to the credibility and open up new relationships with stakeholders (Antolín-López et al., 2016). 
Simona ČINČALOVÁ, Zuzana NOVÁKOVÁ. Corporate social responsibility of the selected transport company operated on the Czech market

As part of improving the communication of CSR activities, it would be appropriate to place information on current ISO certification on its information channels, especially websites (Cho et al., 2017; Reilly \& Larya, 2018).

\section{Conclusions}

Corporate social responsibility is a much-discussed topic since it includes an inexhaustible number of activities in the economic, social and environmental fields. This topic is becoming more and more popular in society and companies are beginning to perceive its influence on it. Some take CSR as a marketing tool, for others, it is an unnecessary extra cost. The more this topic is discussed at a global level, the more some are convinced of the importance of CSR and aware of the impact on the environment. Only this awareness will help ensure that CSR strategies are properly applied and have a positive impact on society.

It was found that the company is doing very well in CSR activities and has a good portfolio for compiling a comprehensive CSR report, which the authors suggested as one of the measures. Another area suitable for the development of some activities is the ecological part. The company actively supports the ecological approach and behaviour, and it has set some measures, such as ISO 14001 certification at its gas station branches, so it is well on its way to certifying its office buildings. The authors were further assisted in my research by a questionnaire for the subsidiary's employees, which found, among other things, that the employees were interested in CSR activities and would welcome some others, such as blood donation.

The current topic is the Covid-19 pandemic, which also affected the Transport Company. Based on the survey, the company's behaviour and its communication with employees were identified. The questionnaire survey found that employees consider the measures taken for their safety to be correct and acknowledge the actions of their employer.

To limitations of this research, it is the limited time and frame and the pandemic situation as well. Continuing research is very important for the better implementation of CSR activities in the company.

\section{References}

Abeysekera, A. P., \& Fernando, C. S. (2020). Corporate social responsibility versus corporate shareholder responsibility: A family firm perspective. Journal of Corporate Finance, 61, Article 101370. https://doi.org/10.1016/j.jcorpfin.2018.05.003

Antolín-López, R., Delgado-Ceballos, J., \& Montiel, I. (2016). Deconstructing corporate sustainability: a comparison of different stakeholder metrics. Journal of Cleaner Production, 136, 5-17. https://doi.org/10.1016/j.jclepro.2016.01.111

Arimany Serrat, N., Sabata Aliberch, A., \& de Uribe Gil, C. E. (2019). Corporate Social Responsibility in passenger transport companies. Intangible Capital, 15(2), 143-156. https://doi.org/10.3926/ic.1356

Bučiūnienè, I., \& Kazlauskaitè, R. (2012). The linkage between HRM, CSR and performance outcomes. Baltic Journal of Management, 7(1), 5-24. https://doi.org/10.1108/17465261211195856

Dahlsrud, A. (2008). How corporate social responsibility is defined: An analysis of 37 definitions. Corporate Social Responsibility and Environmental Management, 15(1), 1-13. https://doi.org/10.1002/csr.132

Gershon, R., \& Cryder, C. (2018). Goods donations increase charitable credit for low-warmth donors. Journal of Consumer Research, 45(2), 451-469. https://doi.org/10.1093/jcr/ucx126

Chalupa, S., Petricek, M., \& Chadt, K. (2021). Improving service quality using text mining and sentiment analysis of online reviews. Quality-Access to Success, 22(182), 46-49. https://www.proquest.com/ openview/1a8cb638b9dd998877228ddd3eabb24c/1?pq-origsite=gscholar\&cbl=1046413

OF MANAGEMENT

IN THE $21^{\text {st }}$ CENTURY

Vol. 16, No. 2, 2021 
Simona ČINČALOVÁ, Zuzana NOVÁKOVÁ. Corporate social responsibility of the selected transport company operated on the Czech market

\section{PROBLEMS \\ OF MANAGEMENT \\ IN THE $21^{\text {st }}$ CENTURY Vol. 16, No. 2, 2021}

Chen, Z., Hang, H., Pavelin, S., \& Porter, L. (2020). Corporate social (ir) responsibility and corporate hypocrisy: Warmth, motive and the protective value of corporate social responsibility. Business Ethics Quarterly, 30(4), 486-524. https://doi.org/10.1017/beq.2019.50

Cho, M., Furey, L. D., \& Mohr, T. (2017). Communicating corporate social responsibility on social media: Strategies, stakeholders, and public engagement on corporate Facebook. Business and Professional Communication Quarterly, 80(1), 52-69. https://doi.org/10.1177\%2F2329490616663708

Lee, Y. K., Lee, K. H., \& Li, D. X. (2012). The impact of CSR on relationship quality and relationship outcomes: A perspective of service employees. International Journal of Hospitality Management, 31(3), 745-756. https://doi.org/10.1016/j.ijhm.2011.09.011

Licandro, O. (2017). The relationship between corporate volunteering and corporate social responsibility: results of an empirical study. Ekonomski vjesnik: Review of Contemporary Entrepreneurship, Business, and Economic Issues, 30(1), 67-83. https://hrcak.srce.hr/ojs/index.php/ekonomskivjesnik/article/view/4580

Martin, U. B. (2020). Derechos humanos y responsabilidad social corporativa en las empresas de transporte. Un apunte de Derecho europeo [Human rights and corporate social responsibility in transport companies. A note on European Law]. Cuadernos Europeos de Deusto, 63, 269-294. https://doi.org/10.18543/ced-63-2020pp269-294

Modak, N. M., \& Kelle, P. (2021). Using social work donation as a tool of corporate social responsibility in a closed-loop supply chain considering carbon emissions tax and demand uncertainty. Journal of the Operational Research Society, 72(1), 61-77. https://doi.org/10.1080/01605682.2019.1654413

Öztay, H., \& Birinci, E. (2019). The corporate social responsibility perception and sustainable consumption behavior of the employees in forest products industry enterprises: The case of Western Black Sea section. Forestist, 70(1), 36-43. https://doi.org/10.5152/forestist.2020.19025

Peloza, J., \& Shang, J. (2011). How can corporate social responsibility activities create value for stakeholders? A systematic review. Journal of the academy of Marketing Science, 39(1), 117-135. https://doi.org/10.1007/s11747-010-0213-6

Redwood, M. (2013). Corporate social responsibility and the carbon footprint of leather. Journal of the Society of Leather Technologists and Chemists, 97(2), 47-55. https://researchportal.bath.ac.uk/en/ publications/corporate-social-responsibility-and-the-carbon-footprint-of-leath

Reilly, A. H., \& Larya, N. (2018). External communication about sustainability: Corporate social responsibility reports and social media activity. Environmental Communication, 12(5), 621-637. https://doi.org/10.1080/17524032.2018.1424009

Sankar, J. P. (2021). Social responsibility of the corporate: Thirukkural perspective. International Journal of Indian Culture and Business Management, 23(1), 83-94. https://www.inderscienceonline.com/ doi/abs/10.1504/IJICBM.2021.115405

Saz-Gil, M. I., Cosenza, J. P., Zardoya-Alegría, A., \& Gil-Lacruz, A. I. (2020). Exploring corporate social responsibility under the background of sustainable development goals: A proposal to corporate volunteering. Sustainability, 12(12), Article 4811. https://doi.org/10.3390/su12124811

Turban, D. B., \& Greening, D. W. (1996). Corporate social performance and organizational attractiveness to prospective employees. Academica Management Journal, 40, 658-672. https://doi.org/10.2307/257057

Ullah, S., \& Sun, D. (2021). Corporate social responsibility corporate innovation: A cross-country study of developing countries. Corporate Social Responsibility and Environmental Management, 28(3), 1066-1077. https://doi.org/10.1002/csr.2106

Velinov, E., \& Cincalova, S. (2021). Corporate social responsibility and internationalization of Czech transport enterprises.19th International Scientific Conference on Hradec Economic Days 2021, 11(1), 842-848.

Vilanova, M., Lozano, J. M., \& Arenas, D. (2009). Exploring the nature of the relationship between CSR and competitiveness. Journal of Business Ethics, 87(1), 57-69. https://doi.org/10.1007/s10551-008-9812-2

Vurro, C., \& Perrini, F. (2011). Making the most of corporate social responsibility reporting: Disclosure structure and its impact on performance. Corporate Governance: The International Journal of Business in Society, 11(4), 459-474. https://doi.org/10.1108/14720701111159280 
Simona ČINČALOVÁ, Zuzana NOVÁKOVÁ. Corporate social responsibility of the selected transport company operated on the Czech market

PROBLEMS

OF MANAGEMENT

IN THE $21^{\text {st }}$ CENTURY

Vol. 16, No. 2, 2021

73

Received: November 16, 2021

Accepted: December 06, 2021

Cite as: Činčalová, S., \& Nováková, Z. (2021). Corporate social responsibility of the selected transport company operated on the Czech market. Problems of Management in the $21^{\text {st }}$ Century, 16(2), 65-73. https://doi.org/10.33225/pmc/21.16.65

Simona Činčalová

(Corresponding author)
PhD, Academic Researcher, College of Polytechnics Jihlava, Tolstého 16, Jihlava, 586 01, Czech Republic.

E-mail: simona.cincalova@vspj.cz

ORCID: https://orcid.org/0000-0003-0830-233X

Zuzana Nováková
Ing, Graduate, College of Polytechnics Jihlava, Tolstého 16, Jihlava, 586 01, Czech Republic.

E-mail: zuzana-novak@seznam.cz 